\title{
PENGARUH PENAMBAHAN VARIASI KONSENTRASI TEPUNG ROSELLA (Hibiscus sabdariffa Linn) TERHADAP SIFAT ORGANOLEPTIK COOKIES ALMOND CRISPY
}

\author{
Oleh: \\ Akhmad Zakaria \\ Niar Nurdiani \\ Program Studi Teknologi Pertanian, Fakultas Teknologi Pertanian, Universitas AlGhifari \\ Jl. Cisaranten Kulon No. 140, Kota Bandung, Jawa Barat 40293
}

\begin{abstract}
Abstrak
Salah satu jenis kue kering yang sedang trend di masyarakat tiga tahun belakang ini adalah cookies almond crispy. Salah satu bahan yang dapat dimanfaatkan pada pembuatan cookies adalah tepung rosella. Tujuan dari penelitian ini adalah mengetahui pengaruh penambahan variasi konsentrasi tepung rosella terhadap kualitas cookies almond crispy baik warna, rasa, aroma dan teksturnya dan juga mendapatkan fomulasi terbaik cookies almond crispy yang disukai oleh panelis. Rancangan penelitian yang digunakan adalah Rancangan Acak Lengkap (RAL) dengan 1 perlakuan dan 6 taraf yaitu penambahan tepung rosella sebanyak 2,2\%; 3,3\%, 4,4\%; 5,5\%; 6,6\%; dan $0 \%$. Panelis dikelompokkan sebagai ulangan, pada Rancangan Acak Lengkap (RAL), panelis diasumsikan sebagai ulangan yang seragam. Pengujian dilakukan oleh 30 orang panelis terhadap sifat organoleptik yang meliputi uji hedonik terhadap warna, rasa, aroma, dan tekstur dengan skala hedonik sangat tidak suka, tidak suka, agak suka, suka, sangat suka. Data hasil uji kesukaan ranking diolah secara statistik non parametric berupa Uji Kruskall Wallis menggunakan SPSS 16.0. Bila hasil analisis sidik ragam tersebut menunjukan nilai yang berpengaruh nyata, maka akan dilanjutkan dengan uji Duncan untuk menunjukkan nilai yang berbeda nyata pada data yang diperoleh. Hasil penelitian, menunjukkan bahwa tingkat kesukaan warna, rasa, aroma, dan tekstur dari cookies almond crispy dengan penambahan tepung rosella sebanyak 3,3\% paling disukai panelis, kemudian diikuti berturut-turut dengan perlakuan penambahan tepung rosella sebanyak 2,2 $\% ; 5,5 \%, 4,4 \% ; 6,6 \%$, dan $0 \%$.
\end{abstract}

Kata kunci : Cookies, Organoleptik, Rosella, Kruskall wallis.

\begin{abstract}
One type of pastry that is trending in the community three years back is crispy almond cookies. One ingredient that can be used in making cookies is rosella flour. The purpose of this study was to determine the effect of adding variations in the concentration of rosella flour on the quality of crispy almond cookies both in color, taste, aroma and texture and also to get the best formulation of crispy almond cookies favored by panelists. The research design used was a Completely Randomized Design (CRD) with 1 treatment and 6 levels, namely the addition of $2.2 \%$ rosella flour; $3.3 \%, 4.4 \% ; 5.5 \%$; $6.6 \%$; and $0 \%$. Panelists were classified as replicates, in a Completely Randomized Design (CRD), panelists were assumed to be uniform tests. Tests carried out by 30 panelists on organoleptic properties which include hedonic tests on color, taste, aroma, and texture with hedonic scale very dislike, dislike, rather like, rather like, like, like very much. The ranking preference test results are processed using non parametric statistics in the form of Kruskall Wallis Test using SPSS 16.0. If the analysis results of the variance show that the value has a significant effect, it will be continued with the Duncan test to show significantly different values on the data obtained. The results
\end{abstract}

\begin{tabular}{|c|c|c|}
\hline JH & PENAMBAHAN & VA \\
\hline ASI & TEPUNG & ROSELLA \\
\hline arift & Linn & AP \\
\hline $\begin{array}{l}\text { ORGANOLEPTIK } \\
\text { CRISPY }\end{array}$ & COOKIES & AI \\
\hline
\end{tabular}

AKHMAD ZAKARIA dan NIAR NURDIANI 
of the study, showed that the level of color, taste, aroma, and texture preferences of crispy almond cookies with the addition of rosella flour as much as 3.3\% was the panelists' most preferred, then followed consecutively with the addition of $2.2 \%$ rosella flour treatment; $5.5 \%, 4.4 \% ; 6.6 \%$, and $0 \%$.

Keywords: cookies, organoleptic, rosella, Kruskall Wallis 


\section{PENDAHULUAN}

Salah satu jenis kue kering yang sedang trend di masyarakat tiga tahun belakang ini adalah cookies almond crispy. Kue ini pertama muncul sebagai salah satu cemilan khas Surabaya, dibuat home made dengan rasa keju. Kemudian berkembang dan bermunculan berbagai variannya di beberapa kota di Indonesia. Banyak yang menggemari kue ini karena tekstur krispi dan rasanya yang manis. Yang membuat istimewa kue ini adalah taburan keju dan almondnya. Selain itu bentuknya yang tipis, lembut dan renyah di mulut (Sartika, 2018).

Dalam membuat kue kering tidak harus selalu memakai tepung terigu, tapi bisa juga dengan tepung gandum, tepung ganyong, tepung ubi jalar dan lainnya. Seiring dengan meningkatnya jumlah penduduk menuntut dipenuhinya kebutuhan pokok rakyat, terutama pangan. Untuk itu perlu dilakukan berbagai terobosan dalam upaya mencari alternatif makanan baru. Indonesia dikenal sebagai negara yang subur, kaya akan hasil alam, namun belum dimanfaatkan secara optimal. Salah satu tanaman yang bisa digunakan sebagai bahan untuk membuat kue kering, antara lain rosella (Winarti, 2006).

Rosella (Hibiscus sabdariffa Linn.) adalah tanaman perdu yang kaya akan manfaat dalam kesehatan. Tanaman rosella bisa mencapai 3-5 meter tingginya dan mempunyai bunga yang berwarna merah. Berbagai produk olahan rosella bisa ditemukan baik dalam bentuk sirup, es krim, permen, teh rosella, maupun dalam bentuk olahan obat-obatan tradisional. (Widyanto, 2009).

Zat aktif yang paling berperan aktif pada kelopak bunga rosella antara lain gossypetin, anthosianin, dan glucoside hibiscin. Beberapa penelitian tentang khasiat rosella sudah banyak dilakukan. Pada tahun 2009, Munawaroh menyimpulkan ekstrak kelopak rosella dapat memberikan pengaruh yang nyata pada peningkatan jumlah eritrosit dan kadar hemoglobin pada darah tikus percobaan. Sedangkan pada tahun 2005 Didah Nurfaridah, dalam penelitiannya menemukan bahwa kandungan antioksidan dalam kelopak bunga rosella mempunyai kadar yang jauh lebih tinggi dibandingkan dengan tanaman kumis kucing. Kelopak bunga rosella mempunyai kandungan vitamin C dan vitamin B yang cukup tinggi. Yang bermanfaat bagi kesehatan. Kandungan antioksidan terdapat pada kelopak bunga rosella, dan dapat menangkal radikal bebas. (Wulandari, dkk. 2014).

Pada penelitian ini akan digunakan tepung rosella sebagai tambahan tepung terigu dalam pembuatan cookies almond crispy. Akan dibuat berbagai variasi konsentrasi tepung rosella sehingga diperoleh formula cookies rosella almond crispy yang terbaik baik warna, rasa, aroma dan teksturnya.

\section{METODE PENELITIAN}

Penelitian dilakukan di Istana Bakery mulai bulan September sampai dengan Oktober 2018. Bahan yang digunakan dalam pembuatan rosella almond crispy antara lain tepung terigu, putih telur, butter, full cream, gula halus dan margarin. Bahan yang digunakan untuk hiasan atas kue adalah irisan kacang almond dan parutan keju.

\section{Penelitian Pendahuluan}

Penelitian pendahuluan yang dilakukan yaitu menentukan formula basis cookies almond crispy Tabel 1. Tujuan penelitian pendahuluan adalah untuk menentukan formula perlakuan pada pembuatan cookies rosella almond crispy yang akan dilakukan pada penelitian utama. Pengamatan hasil penelitian pendahuluan dilihat dari formula basis yang digunakan pada pembuatan cookies rosella almond crispy dan uji organoleptik yang meliputi warna, aroma, rasa, dan tekstur.

Formulasi cookies dalam penelitian ini menggunakan formula Dewi (2011) sebagai formula dasar. Formula dasar ini selanjutnya dimodifikasi dengan resep cookies yang ditambahkan tepung rosella. Modifikasi yang dilakukan meliputi penambahan gula halus, mentega dan margarin. Formula Dewi (2011) dapat dlihat pada Tabel 2. 
Taraf penambahan konsentrasi tepung rosella $2,2 \%, 3,3 \%, 4,4 \%$ dan $5,5 \%, 6,6 \%$, dan $0 \%$ dari total adonan. Variasi konsentrasi ini berdasarkan modifikasi dari penelitian Aina (2014) pada pembuat biskuit dengan penggunaan

Tabel 1. Formula Basis Cookies Almond Crispy. konsentrasi tepung daun kelor sebesar $5 \%, \quad 7.5 \%$, dan $10 \%$. Formula yang digunakan adalah Modifikasi Formula Dewi (2012). Formula yang digunakan dalam pembuatan cookies ini dapat dilihat pada tabel 1 .

\begin{tabular}{clccc}
\hline \multirow{2}{*}{ No } & & Bahan & \multicolumn{2}{c}{ Jumlah } \\
\cline { 3 - 4 } & & gram & \% \\
\hline 1 & Tepung terigu & 200 & 22,2 \\
2 & Putih telur & 200 & 22,2 \\
3 & Margarin & 175 & 19,5 \\
4 & Butter & 75 & 8,3 \\
5 & Gula halus & 175 & 19,5 \\
6 & Full cream & 75 & 8,3 \\
\hline & & Total & 900 & 100 \\
\hline
\end{tabular}

Tabel 2. Formula Dewi 2011.

\begin{tabular}{|c|c|c|c|c|}
\hline \multirow{2}{*}{ Bahan } & \multicolumn{4}{|c|}{ Jumlah } \\
\hline & F0 * & F1 * & F2* & F3* \\
\hline Pati garut & 125 & 125 & 125 & 125 \\
\hline Tepung torbangun & 0 & 12,5 & 18,75 & 25 \\
\hline Susu skim & 30 & 30 & 30 & 30 \\
\hline Gula halus & 40 & 40 & 40 & 40 \\
\hline Mentega & 30 & 30 & 30 & 30 \\
\hline Margarine & 30 & 30 & 30 & 30 \\
\hline Telur & 18 & 18 & 18 & 18 \\
\hline Berat total & 127 & 285,5 & 291,75 & 298 \\
\hline
\end{tabular}

Tabel 3. Formula Cookies Rosella Almond Crispy

\begin{tabular}{|l|c|c|c|c|c|c|c|c|c|c|c|c|}
\hline \multirow{2}{*}{ Bahan } & \multicolumn{2}{|c|}{$\mathrm{A}^{*}$} & \multicolumn{2}{|c|}{$\mathrm{B}^{*}$} & \multicolumn{2}{|c|}{$\mathrm{C}^{*}$} & \multicolumn{2}{|c|}{$\mathrm{D}^{*}$} & \multicolumn{2}{|c|}{$\mathrm{E}^{*}$} & \multicolumn{3}{|c|}{$\mathrm{F}^{*}$} \\
\cline { 2 - 14 } & $\mathrm{g}$ & $\%$ & $\mathrm{~g}$ & $\%$ & $\mathrm{~g}$ & $\%$ & $\mathrm{~g}$ & $\%$ & $\mathrm{~g}$ & $\%$ & $\mathrm{~g}$ & $\%$ \\
\hline $\begin{array}{l}\text { Tepung } \\
\text { Rosella }\end{array}$ & 20 & 2,2 & 30 & 3.3 & 40 & 4.4 & 50 & 5.5 & 60 & 6.6 & 0 & 0 \\
\hline $\begin{array}{l}\text { Tepung } \\
\text { Terigu }\end{array}$ & 200 & 21.73 & 200 & 21,5 & 200 & 21,2 & 200 & 21 & 200 & 20,8 & 200 & 22,2 \\
\hline $\begin{array}{l}\text { Putih } \\
\text { Telur }\end{array}$ & 200 & 21.73 & 200 & 21,5 & 200 & 21,2 & 200 & 21 & 200 & 20,8 & 200 & 22,2 \\
\hline Margarin & 175 & 19,02 & 175 & 18.8 & 175 & 18,6 & 175 & 18,4 & 175 & 18,1 & 175 & 19,5 \\
\hline Butter & 75 & 8,15 & 75 & 8.05 & 75 & 8 & 75 & 7,8 & 75 & 7,8 & 75 & 8.3 \\
\hline $\begin{array}{l}\text { Gula } \\
\text { Halus }\end{array}$ & 175 & 19,02 & 175 & 18,8 & 175 & 18,6 & 175 & 18,4 & 175 & 18,1 & 175 & 19,5 \\
\hline $\begin{array}{l}\text { Full } \\
\text { Cream }\end{array}$ & 75 & 8,15 & 75 & 8.05 & 75 & 8 & 75 & 7,8 & 75 & 7,8 & 75 & 8.3 \\
\hline--
\end{tabular}

Ket : * merupakan formüla Dewi (2011) dengan modifikasi.

\section{Penelitian Utama}

Penelitian utama bertujuan untuk mengetahui formula cookies rosella almond crispy terbaik serta mengetahui profil kesukaan masyarakat dengan menggunakan uji hedonik yang meliputi aspek warna, rasa, aroma dan tekstur. Penelitian utama yang dilakukan terdiri dari rancangan perlakuan, rancangan percobaan, rancangan analisis, dan rancangan respon. 


\section{Rancangan Perlakuan}

Rancangan perlakuan pada penelitian utama terdiri dari satu faktor yaitu perbandingan variasi konsentrasi tepung rosella dan tepung terigu. Pada pembuatan cookies rosella almond crispy ini dibuat 6 sampel, yaitu 5 sampel variasi konsentrasi tepung rosella dan 1 sampel pembanding.

Penelitian ini terdiri dari 6 taraf penambahan variasi konsentrasi tepung rosella yaitu:

1. Tepung rosella $2,2 \%$ diberi kode $A$

2. Tepung rosella $3,3 \%$ diberi kode $B$

3. Tepung rosella $4,4 \%$ diberi kode $C$

4. Tepung rosella $5,5 \%$ diberi kode $\mathrm{D}$

5. Tepung rosella $6,6 \%$ diberi kode $\mathrm{E}$

6. Tepung rosella $0 \%$ diberi kode $\mathrm{F}$

\section{Rancangan Percobaan}

Rancangan percobaan yang digunakan pada penelitian ini adalah Rancangan Acak Lengkap (RAL). Model matematika yang digunakan untuk rancangan ini adalah sebagai berikut :

$$
Y_{i j}=\mu+A_{i}+\epsilon_{i j}
$$

Dimana:

Yij : Hasil pengamatan dari perlakuan ke-i dalam ulangan ke-j

$\mu \quad$ : Nilai tengah Umum

$A_{i} \quad$ : Pengaruh perlakuan ke-i

$\epsilon_{\mathrm{ij}}$ : Galat percobaan pada perlakuan kei dan ulangan ke $-\mathrm{j}$

Berdasarkan rancangan tersebut di atas dapat dibuat analisis variansi (ANOVA).

\section{Rancangan Analisis}

Dalam rancangan analisis ini digunakan metode uji kruskall wallis. Metode ini dapat digunakan untuk mengetahui apakah hipotesis yang diajukan diterima atau ditolak. Berdasarkan rancangan diatas maka dapat dibuat analisis untuk mendapatkan kesimpulan mengenai pengaruh perlakuan. Statistik uji kruskall wallis dapat diperoleh melalui rumus berikut.

$$
H=\frac{12 N}{(N+1)} \sum_{i=1} k \frac{r i^{2}}{n i}-3(N+1)
$$

Catatan :

$\mathrm{k}$ = banyaknya sampel

ni = banyaknya kasus pada setiap sampel

ke-i

$\mathrm{N}=\sum n i=$ banyaknya seluruh kasus

ri $=$ total ranking untuk setiap sampel ke-i

$\sum \mathrm{ki}=1=$ menunjukkan penjumlahan

seluruh $k$ sampel (kolom-kolom)

mendekati distribusi Chi square

dengan $\mathrm{db}=k-1$ untuk ukuran ukuran sampel sebesar $n$ yang cukup besar.

Sumber : statistik non parametrik untuk

ilmu-ilmu sosial karangan Sidney siegel .

Berdasarkan rancangan di atas, untuk mendapatkan kesimpulan mengenai pengaruh perlakuan akan ditentukan oleh hipotesisnya $\left(\mathrm{H}_{1}\right)$, yaitu:

1) $\mathrm{H}_{1}$ ditolak, jika Asymtotic significance $>0,005$, maka tidak ada pengaruh antara rata-rata dari setiap perlakuan, artinya perlakuan yang diberikan tidak berpengaruh terhadap karakteristik cookies.

2) $\mathrm{H}_{1}$ diterima, jika Asymtotic significance $<0,005$, maka ada pengaruh antara rata-rata dari setiap perlakuan, artinya perlakuan yang diberikan berpengaruh terhadap karakteristik cookies yang dihasilkan.

Kesimpulan dari hipotesis di atas adalah ditolak jika tidak berbeda nyata antara rata-rata dari masing-masing perlakuan. Sedangkan hipotesis diterima jika terdapat beda nyata antara rata-rata dari masing-masing perlakuan. Jika terdapat perbedaan yang nyata antara perlakuan, maka analisis data dilanjutkan dengan uji lanjut uji jarak berganda Duncan pada taraf signifikansi 5\%.

\section{Rancangan Respon}

Rancangan respon yang akan dilakukan dalam penelitian utama adalah respon organoleptik. Analisis organoleptik menggunakan metode hedonik. Uji organoleptik dilakukan terhadap warna, 
aroma, rasa, dan tekstur dari cookies rosella almond crispy yang diujikan kepada panelis untuk dinilai dari masing-masing perlakuan. Uji organoleptik dilakukan berdasarkan tingkat kesukaan panelis dengan menggunakan skala hedonik. Kriteria skala hedonik dapat dilihat pada tabel 3.4.

\section{HASIL DAN PEMBAHASAN}

Hasil penilaian terhadap 30 panelis ditunjukkan pada gambar 1. Pada gambar 1 menunjukkan bahwa cookies almond crispy yang diperoleh dari 6 perlakuan memberikan penilaian warna sangat tidak suka hingga sangat suka. Hasil nilai ratarata penilaian dari 30 panelis dengan menggunakan metode hedonik melalui pengujian organoleptik, panelis memberikan nilai skor terhadap warna cookies almond crispy yaitu 2,67 - 3,50.
Hasil uji organoleptik terhadap warna menunjukkan warna yang paling disukai oleh panelis adalah cookies almond crispy dengan penambahan tepung rosella sebanyak 2,2\% dengan skor rata-rata 3,5, dan yang paling tidak disukai oleh panelis adalah tanpa penambahan tepung rosella dengan skor rata-rata 2,67. Skor yang berbeda tersebut disebabkan oleh penambahan tepung rosella.

Dari hasil uji Kruskal Wallis didapati Asymp.Sig. 0,006 yang lebih kecil dari tingkat signifikan 0,05 . Oleh karena itu, berdasarkan uji statistik maka disimpulkan bahwa semua perlakuan terbukti berbeda nyata terhadap kesukaan panelis terhadap warna cookies almond keju yang dihasilkan. Selanjutnya dilakukan uji Lanjut DMRT. Hasil dari uji lanjut DMRT pada perlakuan rasa dapat dilihat pada gambar 1 .

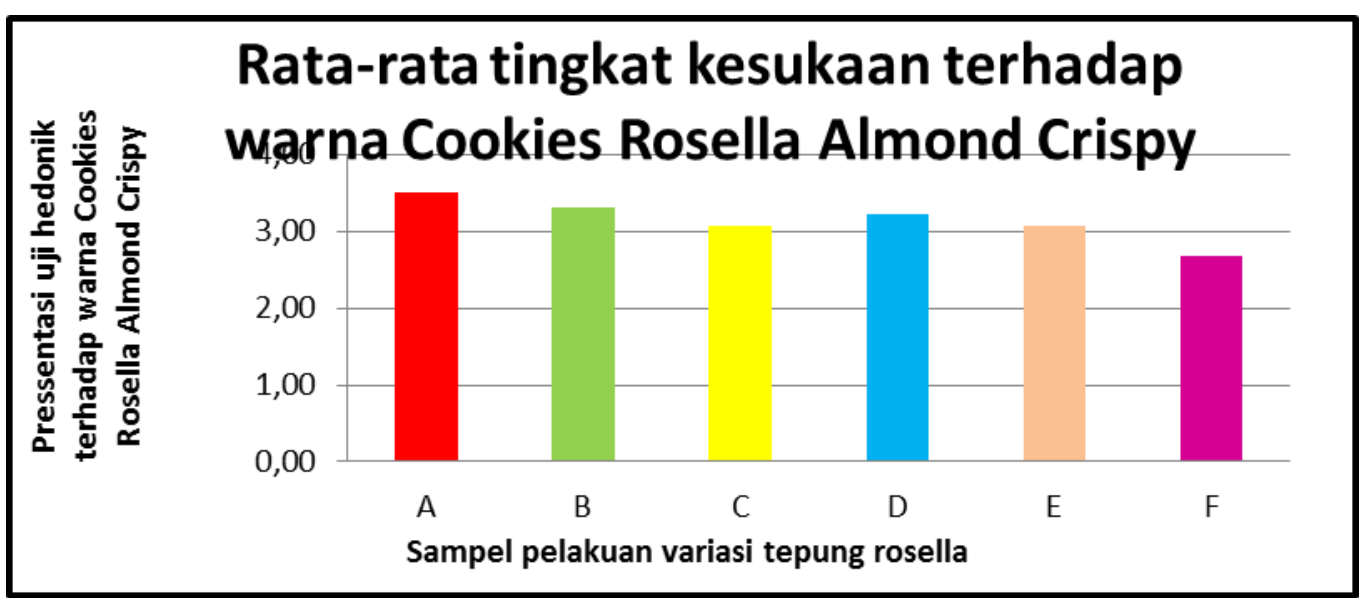

Gambar 1. Hasil uji organoleptik terhadap warna cookies almond crispy.

Penambahan tepung rosella memberikan pengaruh nyata pada tingkat kepercayaan $95 \% \quad(\mathrm{P}<0.05) \quad$ terhadap warna cookies almond crispy. Nilai warna terendah ditunjukkan oleh cookies almond crispy tanpa penambahan tepung rosella dengan nilai 2,67 dengan kriteria tidak suka hingga suka. Sedangkan nilai warna cookies almond crispy dengan penambahan tepung rosella 2,2 \% mempunyai nilai tertinggi dengan kriteria tidak suka hingga sangat suka. Dari nilai warna tersebut dapat diartikan bahwa panelis lebih menyukai warna cookies almond crispy dengan penambahan tepung rosella dibandingkan warna cookies almond crispy tanpa menggunakan tepung rosella.




Tabel 4. Skor hedonik warna cookies almond crispy dengan berbagai penambahan variasi konsentrasi tepung rosella.

\begin{tabular}{cc}
\hline Perlakuan (\%) & Skor Warna \\
\hline A $(2,2 \%)$ & $3,50^{\mathrm{b}}$ \\
B (3,3\%) & $3,30^{\mathrm{b}}$ \\
C $(4,4 \%)$ & $3,07^{\mathrm{ab}}$ \\
D $(5,5 \%)$ & $3,24^{\mathrm{b}}$ \\
E $(6,6 \%)$ & $3,06^{\mathrm{ab}}$ \\
F $(0 \%)$ & $2,67^{\mathrm{a}}$ \\
\hline
\end{tabular}

Superskrip yang berbeda menunjukkan beda nyata $(\mathrm{P}=0,05)$.

Berdasarkan uji DMRT menunjukkan warna cookies almond crispy dengan penambahan berbagai varian konsentrasi tepung rosella berbeda nyata dengan kontrol (tanpa penambahan tepung rosella). Konsentrasi tepung rosella memberikan pengaruh yang nyata terhadap warna cookies almond crispy. Dengan demikian, pada semua varian konsentrasi tepung rosella memberikan warna pada cookies almond crispy yang disukai panelis. Superskrip yang berbeda menunjukkan beda nyata, konsentrasi tepung rosella $2,2 \% ; 3,3 \% ; 4,4 \% ; 5,5 \%$; dan 6,6\% berbeda dengan kontrol (tanpa penambahan tepung rosella). Penambahan tepung rosella pada cookies almond crispy memberikan suatu warna yang berbeda yang terlihat oleh panelis. Penambahan berbagai varian konsentrasi tepung rosella pada penelitian ini menghasilkan warna pink pudar hingga keunguan yang dinilai lebih disukai oleh panelis dari pada warna kuning pudar pada cookies almond crispy tanpa penambahan tepung rosella.

Jumlah tepung rosella yang ditambahkan memberikan pengaruh terhadap warna yang dihasilkan pada produk cookies almond crispy tersebut. Kelopak bunga rosella mengandung hibiscin yang merupakan pigmen utama dalam bunga rosella sebesar 2,5 \% (Winarti, 2006). Tingginya kandungan hibiscin tersebut menjadi faktor utama yang mempengaruhi warna pada cookies almond crispy.

Zat warna alami yang terdapat pada buah rosella di dalam air akan memberikan warna merah terang yang sangat menarik sehingga bubuk serat buah rosella dapat dengan mudah digunakan sebagai bahan makanan fungsional. Zat warna pada kelopak bunga rosella dapat memberikan warna merah yang menarik pada makanan. Menurut Winarno (2004), warna merupakan penentu bahan pangan yang paling utama. Suatu bahan pangan yang bernilai gizi baik belum tentu dinikmati apabila warna suatu bahan pangan/ produk akhir kurang baik atau bahkan memberi kesan telah menyimpang dari warna yang seharusnya. Penentuan mutu suatu bahan pangan pada umumnya tergantung warna, karena yang paling pertama dilihat adalah tampilan warna.

\section{Uji Organoleptik Rasa}

Hasil uji organoleptik terhadap rasa bertujuan untuk mengetahui tingkat respon dari panelis mengenai kesukaannya terhadap cookies almond crispy yang dihasilkan pada masing-masing perlakuan. Hasil penilaian panelis pada gambar 2 menunjukkan bahwa cookies almond crispy yang diperoleh dari 6 perlakuan memberikan penilaian rasa sangat tidak suka hingga sangat suka. Hasil nilai ratarata penilaian dari 30 panelis dengan menggunakan metode hedonik melalui pengujian organoleptik, panelis memberikan nilai skor terhadap rasa cookies almond crispy yaitu 2,33 - 3,60. Hasil uji organoleptik terhadap rasa cookies almond crispy yang dihasilkan menunjukkan bahwa rasa produk cookies almond crispy yang paling disukai panelis yaitu pada perlakuan B (penambahan 3,3 $\%$ tepung rosella) dengan skor 3,60. Sedangkan rasa yang kurang diminati oleh panelis yaitu pada perlakuan F (tanpa penambahan tepung rosella) dengan skor 2,33 .

\begin{tabular}{|c|c|c|}
\hline $\begin{array}{l}\text { PENGARUH } \\
\text { KONSENTRASI }\end{array}$ & $\begin{array}{c}\text { PENAMBAHAN } \\
\text { TEPUNG }\end{array}$ & $\begin{array}{r}\text { VARIASI } \\
\text { ROSELLA }\end{array}$ \\
\hline (Hibiscus sabdari & iffa Linn) TERHA & SIFAT \\
\hline $\begin{array}{l}\text { ORGANOLEPTIY } \\
\text { CRISPY }\end{array}$ & COOKIES & ALMOND \\
\hline
\end{tabular}


Dari hasil uji Kruskal Wallis didapati Asymp.Sig. 0,000 yang lebih kecil dari tingkat signifikan 0,05 . Oleh karena itu, berdasarkan uji statistik maka disimpulkan bahwa semua perlakuan terbukti berbeda nyata terhadap kesukaan panelis terhadap warna cookies almond keju yang dihasilkan. Selanjutnya dilakukan uji Lanjut DMRT. Hasil dari uji lanjut DMRT pada perlakuan rasa dapat dilihat pada gambar 2 .

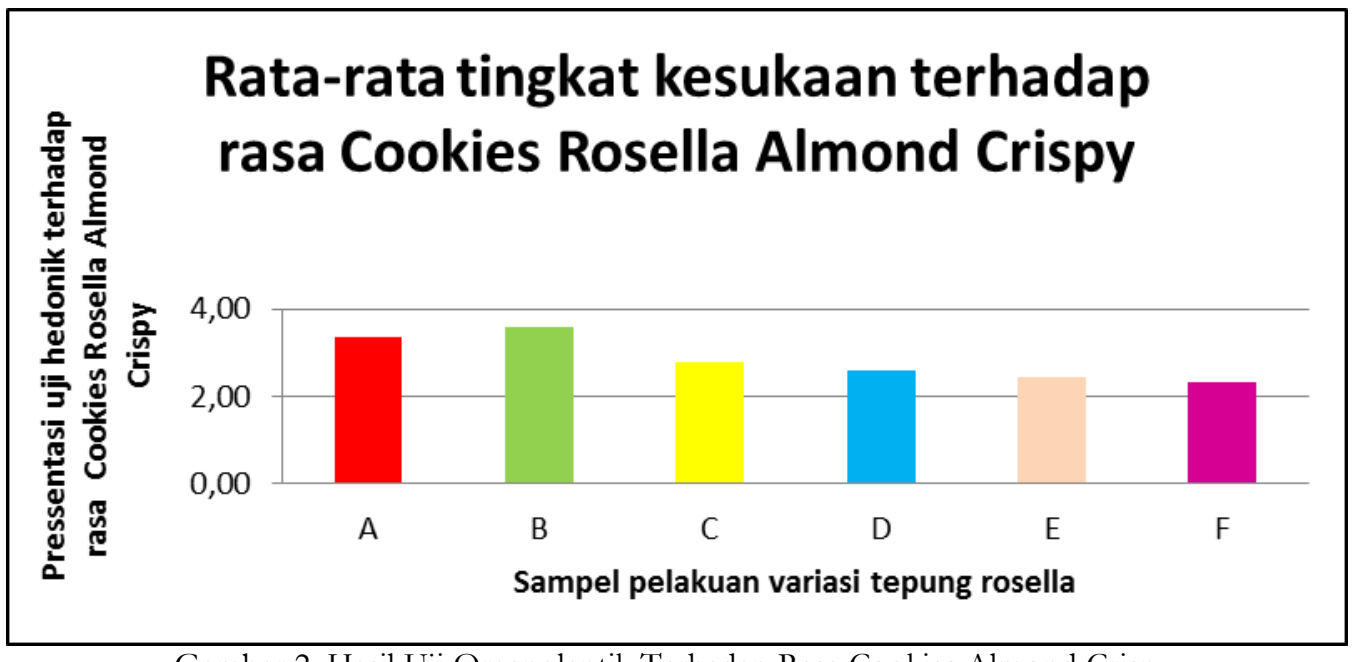

Gambar 2. Hasil Uji Organoleptik Terhadap Rasa Cookies Almond Crispy.

Hasil penelitian memperlihatkan nilai skor rasa cookies almond crispy dengan penambahan variasi konsentrasi tepung rosella berkisar antara 2,33 - 3,60. Data hasil penelitian disajikan pada tabel 5.

Tabel 5. Skor hedonik rasa cookies almond crispy dengan berbagai penambahan variasi konsentrasi tepung rosella.

\begin{tabular}{cc}
\hline Perlakuan (\%) & Skor Rasa \\
\hline A $(2,2 \%)$ & $3,37^{\mathrm{b}}$ \\
B (3,3\%) & $3,60^{\mathrm{b}}$ \\
C (4,4\%) & $2,80^{\mathrm{a}}$ \\
D $(5,5 \%)$ & $2,59^{\mathrm{a}}$ \\
E (6,6\%) & $2,45^{\mathrm{a}}$ \\
F $(0 \%)$ & $2,33^{\mathrm{a}}$ \\
\hline
\end{tabular}

Superskrip yang berbeda menunjukkan beda nyata $(\mathrm{P}=0,05)$.

Penambahan tepung rosella memberikan pengaruh nyata pada tingkat kepercayaan 95\% $(\mathrm{P}<0.05)$ terhadap rasa cookies almond crispy. Nilai skor rasa terendah diberikan pada rasa cookies almond crispy tanpa penambahan tepung rosella $(0 \%)$ dengan nilai 2,33 dengan kriteria sangat tidak suka hingga agak suka. Sedangkan nilai skor rasa cookies almond crispy dengan penambahan tepung rosella 3,0 \% mempunyai nilai skor tertinggi 3,60 dengan kriteria tidak suka hingga sangat suka. Dari nilai skor rasa tersebut dapat diartikan bahwa panelis lebih menyukai rasa cookies almond crispy dengan penambahan tepung rosella pada konsentrasi yang rendah dibandingkan rasa cookies almond crispy tanpa menggunakan tepung rosella dan penambahan konsentrasi tepung rosella yang lebih tinggi.

Berdasarkan uji DMRT menunjukkan perlakuan A dan B berbeda nyata dengan perlakuan $C, D, E$, dan $F$. Konsentrasi tepung rosella memberikan pengaruh yang nyata terhadap rasa cookies almond crispy. Rasa adalah faktor penting yang mempengaruhi penerimaan suatu produk makanan dan minuman. Jika komponen tampilan baik tetapi konsumen

\begin{tabular}{|c|c|c|}
\hline PENGARUH & PENAMBAHAN & AKHMAD ZAKARIA dan NIAR NURDIANI \\
\hline KONSENTRASI & TEPUNG & \\
\hline (Hibiscus sabdarif & iffa Linn) TERHADAP SIFAT & \\
\hline $\begin{array}{l}\text { ORGANOLEPTIK } \\
\text { CRISPY }\end{array}$ & K COOKIES ALMOND & \\
\hline
\end{tabular}


tidak menyukai rasanya maka konsumen tidak akan menerima produk pangan tersebut (Rampengan dkk., 1985). Penambahan variasi konsentrasi tepung rosella memberikan kontribusi rasa pada cookies almond crispy. Kelopak bunga rosella mengandung campuran asam sitrat dan asam malat sebesar $13 \%$ (Winarti, 2006). Kandungan tersebut mempengaruhi rasa cookies almond crispy. Semakin tinggi konsentrasi tepung rosella yang diberikan menghasilkan rasa yang semakin asam. Perlakuan A dan B paling disukai oleh panelis karena menghasilkan rasa yang pas karena tidak terlalu asam. Menurut Agustini (2006), kandungan nutrisi bunga rosella yang kaya akan vitamin C serta kandungan karbohidrat yang tinggi maka serat bunga rosella memberikan rasa khas yang disukai sehingga bunga rosella sangat prospektif untuk dijadikan sebagai bahan dasar dalam pembuatan makan fungsional.

\section{Uji organoleptik Aroma}

Hasil uji organoleptik terhadap aroma bertujuan untuk mengetahui tingkat respon dari panelis mengenai kesukaannya terhadap variasi penambahan tepung rosella pada cookies almond crispy. Hasil uji organoleptik terhadap aroma pada gambar 3 menunjukkan bahwa cookies almond crispy yang diperoleh dari 6 perlakuan memberikan penilaian aroma sangat tidak suka hingga sangat suka. Hasil nilai rata-rata penilaian dari 30 panelis dengan menggunakan metode hedonik melalui pengujian organoleptik, panelis memberikan skor terhadap aroma cookies almond crispy yaitu 2,43 - 3,23. Hasil uji organoleptik menunjukkan aroma yang paling disukai oleh panelis adalah cookies almond crispy pada perlakuan B dengan skor 3,23, dan yang paling tidak disukai oleh panelis adalah aroma cookies almond crispy perlakuan F dengan skor 2,43.

Dari hasil uji Kruskal Wallis didapati Asymp.Sig. 0,004 yang lebih kecil dari tingkat signifikan 0,05 . Oleh karena itu, berdasarkan uji statistik maka disimpulkan bahwa semua perlakuan terbukti berbeda nyata terhadap kesukaan panelis terhadap warna cookies almond keju yang dihasilkan. Selanjutnya dilakukan uji Lanjut DMRT. Hasil dari uji lanjut DMRT pada perlakuan rasa dapat dilihat pada gambar 3 .

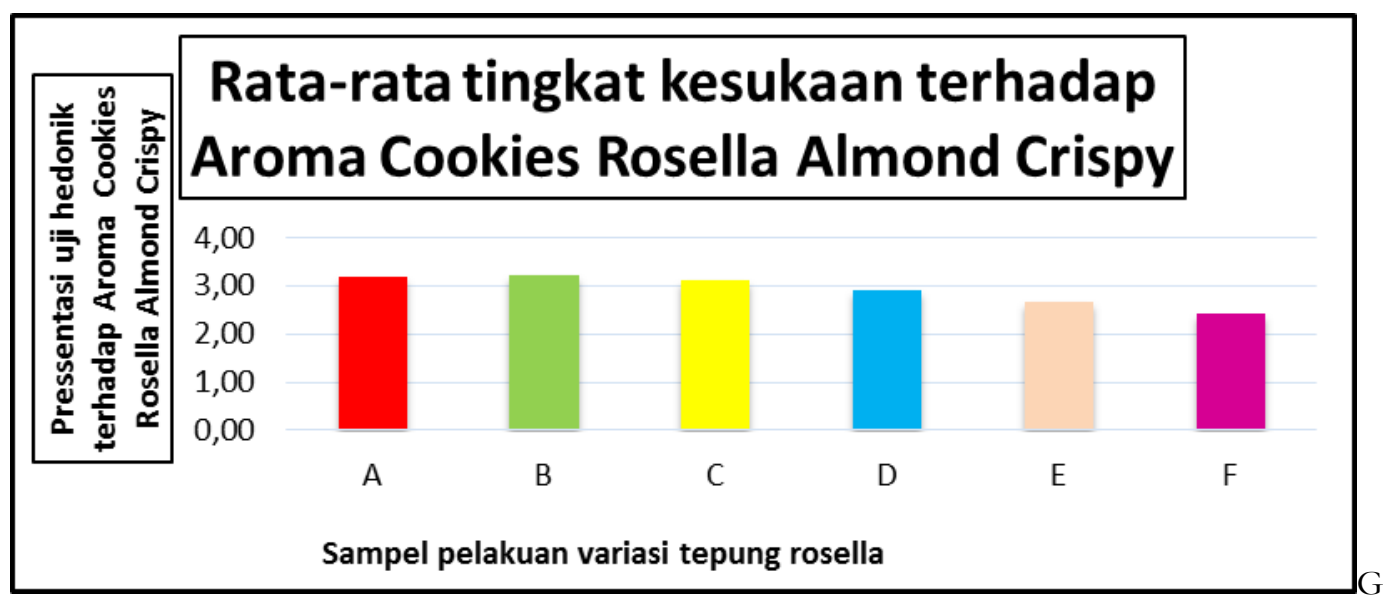

ambar 3. Hasil uji organoleptik terhadap aroma cookies almond crispy.

Hasil penelitian memperlihatkan nilai skor aroma cookies almond crispy dengan penambahan variasi konsentrasi tepung rosella berkisar antara 2,43 - 3,23. Data hasil penelitian disajikan pada tabel 3.

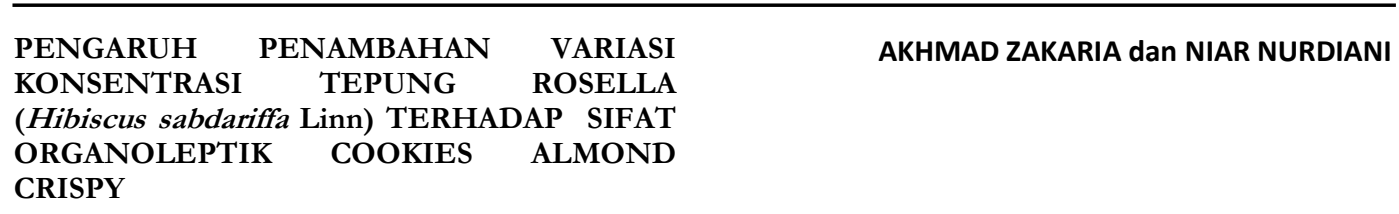


Tabel 3. Skor Hedonik Aroma Cookies Almond Crispy dengan Berbagai Penambahan Variasi Konsentrasi Tepung Rosella

\begin{tabular}{cc}
\hline Perlakuan (\%) & Skor Warna \\
\hline A (2,2\%) & $3,20^{\mathrm{b}}$ \\
B (3,3\%) & $3,23^{\mathrm{b}}$ \\
C (4,4\%) & $3,10^{\mathrm{b}}$ \\
D $(5,5 \%)$ & $2,86^{\mathrm{ab}}$ \\
E (6,6\%) & $2,71^{\mathrm{ab}}$ \\
F $(0 \%)$ & $2,43^{\mathrm{a}}$ \\
\hline
\end{tabular}

Superskrip yang berbeda menunjukkan beda nyata $(\mathrm{P}=0,05)$.

Penambahan tepung rosella memberikan pengaruh nyata pada tingkat kepercayaan 95\% $\quad(\mathrm{P}<0.05) \quad$ terhadap aroma cookies almond crispy. Nilai skor aroma terendah diberikan pada perlakuan F dengan penilaian 2,43 dengan kriteria sangat tidak suka hingga agak suka. Sedangkan nilai skor rasa cookies almond crispy perlakuan B mempunyai nilai skor tertinggi dengan kriteria tidak suka hingga sangat suka. Dari nilai skor aroma tersebut dapat diartikan bahwa panelis lebih menyukai aroma cookies almond crispy dengan penambahan tepung rosella pada konsentrasi yang rendah dibandingkan aroma cookies almond crispy tanpa menggunakan tepung rosella dan penambahan konsentrasi tepung rosella yang lebih tinggi.

Berdasarkan uji DMRT menunjukkan perlakuan $\mathrm{A}, \mathrm{B}, \mathrm{C}$ berbeda nyata dengan perlakuan D, E, dan F. Konsentrasi tepung rosella memberikan pengaruh yang nyata terhadap aroma cookies almond crispy. Menurut Soekarto (1985) aroma merupakan salah satu parameter yang mempengaruhi terhadap persepsi rasa enak dari suatu makanan.

\section{Uji organoleptik Tekstur}

Tekstur produk pangan merupakan salah satu komponen yang dinilai dalam uji organoleptik cookies almond crispy. Hasil penilaian panelis pada gambar 4 menunjukkan bahwa cookies almond crispy yang diperoleh dari 6 perlakuan memberikan penilaian tekstur sangat tidak suka hingga sangat suka. Hasil nilai rata-rata penilaian dari 30 panelis dengan menggunakan metode hedonik melalui pengujian organoleptic, panelis memberikan nilai skor terhadap tekstur cookies almond crispy yaitu 2,633,97. Hasil uji organoleptik terhadap tekstur menunjukkan tekstur yang paling disukai oleh panelis adalah cookies almond crispy pada perlakuan B dengan skor 3,97 dan yang paling tidak disukai oleh panelis adalah tekstur cookies almond crispy pada perlakuan $\mathrm{C}$ dengan skor 2,63.

Dari hasil uji Kruskal Wallis didapati Asymp.Sig. 0,006 yang lebih kecil dari tingkat signifikan 0,05. Oleh karena itu, berdasarkan uji statistik maka disimpulkan bahwa semua perlakuan terbukti berbeda nyata terhadap kesukaan panelis terhadap warna cookies almond keju yang dihasilkan. Selanjutnya dilakukan uji Lanjut DMRT. Hasil dari uji lanjut DMRT pada perlakuan rasa dapat dilihat pada gambar 4.

\begin{tabular}{|c|c|c|}
\hline PENGARUH & PENAMBAHAN & VARIASI \\
\hline KONSENTRASI & TEPUNG & ROSELLA \\
\hline (Hibiscus sabdarif & ffa Linn) TERHA & SIFA \\
\hline $\begin{array}{l}\text { ORGANOLEPTIK } \\
\text { CRISPY }\end{array}$ & COOKIES & ALMOND \\
\hline
\end{tabular}




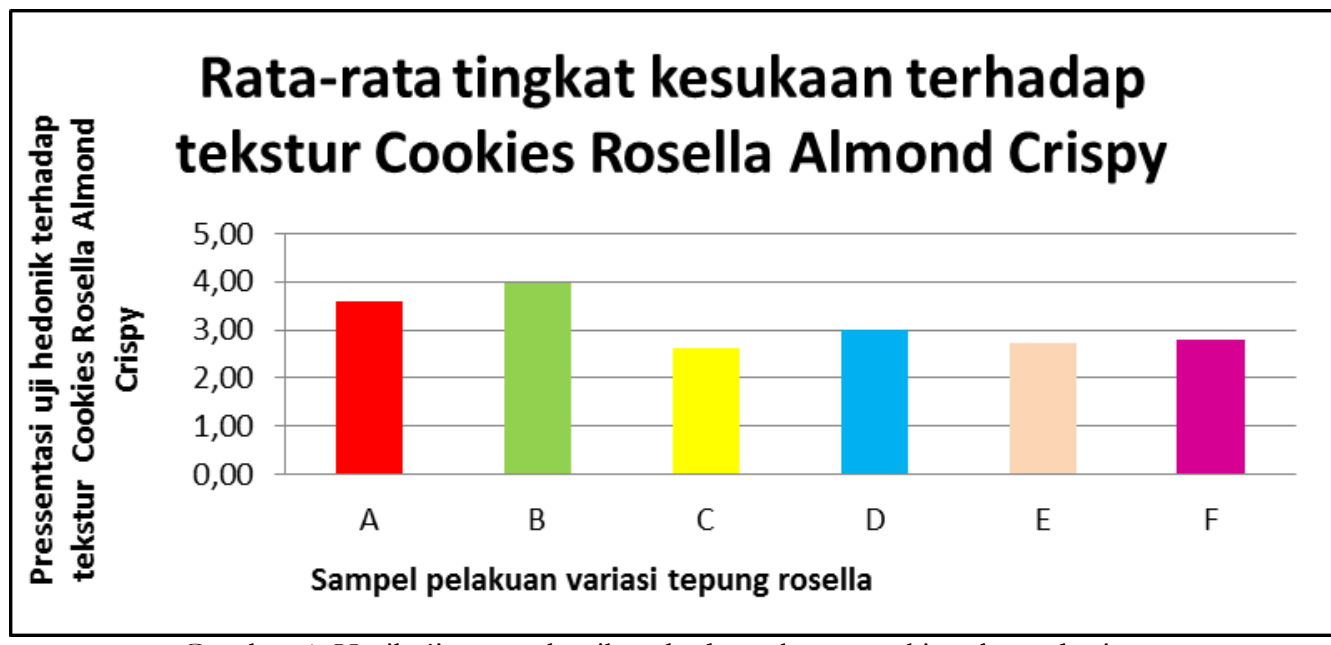

Gambar 4. Hasil uji organoleptik terhadap tekstur cookies almond crispy.

Tabel 4. Skor hedonik tekstur cookies almond crispy dengan berbagai penambahan variasi konsentrasi tepung rosella

\begin{tabular}{cc}
\hline Perlakuan (\%) & Skor Warna \\
\hline A $(2,2 \%)$ & $3,60^{\mathrm{b}}$ \\
B (3,3\%) & $3,97^{\mathrm{b}}$ \\
C $(4,4 \%)$ & $2,63^{\mathrm{a}}$ \\
D $(5,5 \%)$ & $3,03^{\mathrm{a}}$ \\
E $(6,6 \%)$ & $2,71^{\mathrm{a}}$ \\
F $(0 \%)$ & $2,80^{\mathrm{a}}$ \\
\hline
\end{tabular}

Superskrip yang berbeda menunjukkan beda nyata $(\mathrm{P}=0,05)$.

Penambahan tepung rosella memberikan pengaruh nyata pada tingkat kepercayaan 95\% $\quad(\mathrm{P}<0.05)$ terhadap tekstur cookies almond crispy. Nilai skor tekstur terendah diberikan pada tekstur cookies almond crispy dengan penambahan tepung rosella $4,4 \%$ dengan nilai 2,63 dengan kriteria prnilaian sangat tidak suka hingga agak suka. Sedangkan nilai skor tekstur cookies almond crispy dengan penambahan tepung rosella 3,3\% mempunyai nilai skor tertinggi dengan kriteria penialain tidak suka hingga sangat suka. Dari nilai skor rasa tersebut dapat diartikan bahwa panelis lebih menyukai tekstur cookies almond crispy dengan penambahan tepung rosella pada konsentrasi yang rendah dibandingkan tekstur cookies almond crispy tanpa menggunakan tepung rosella dan pada penambahan konsentrasi tepung rosella pada yang lebih tinggi.

Berdasarkan uji DMRT menunjukkan tekstur cookies almond crispy dengan penambahan berbagai varian konsentrasi tepung rosella berbeda nyata dengan kontrol. Konsentrasi tepung rosella memberikan pengaruh yang nyata terhadap tekstur n cookies almond crispy. Dengan demikian, pada semua varian konsentrasi tepung rosella memberikan rasa pada cookies almond crispy yang disukai panelis.

Semakin tinggi konsentrasi tepung rosella yang ditambahkan, tekstur yang dihasilkan semakin padat dan mengerungangi kerenyahan cookies. Semakin banyak konsentrasi tepung rosella yang digunakan maka kandungan pektin akan semakin tinggi. Hal tersebut disebabkan karena pektin adalah senyawa hidrokoloid dapat digolongkan kedalam serat yang merupakan polisakarida yang mudah larut dalam air. Tekstur yang dihasilkan berhubungan dengan kadar air cookies almond crispy. Menurut Rahadian (2017), kadar air sangat dipengaruhi oleh daya ikat pektin terhadap air. Ikatan-ikatan di dalam struktur pektin bersifat amorf (tidak 
berbentuk pasti) yang dapat mengembang bila molekul air terjerat. Jumlah gugus $\mathrm{OH}$ yang banyak pada pektin menyebabkan pektin banyak mengikat air. Pektin pada ekstrak kelopak bunga rosella sangat berpengaruh terhadap tekstur yang dihasilkan sehinga semakin meningkatnya kadar pektin yang digunakan maka tingkat kepadatan yang dihasilkan akan semakin tinggi. Hal ini yang menyebabkan cookies menjadi tidak renyah dan kurang disukai panelis.

\section{Cookies Almond Crispy Perlakuan Terbaik}

Rata-rata dari hasil uji organoleptik yang meliputi warna, aroma, tekstur, dan rasa terhadap cookies almond crispy dengan penambahan tepung rosella yang dihasilkan setiap perlakuan dapat dilihat pada gambar 5. Hasil nilai rata-rata penilaian dari 30 panelis memberikan nilai terhadap warna, aroma, tekstur, dan rasa cookies almond crispy yaitu $2,56-3,53$. Hasil uji organoleptik menunjukkan cookies almond crispy yang paling disukai oleh panelis adalah cookies almond crispy pada perlakuan B dengan skor 3,53. Sedangkan cookies almond crispy yang paling tidak disukai oleh panelis adalah pada perlakuan F. Cookies almond crispy pada perlakuan B yaitu cookies almond crispy dengan perlakuan terbaik, karena memiliki karakteristik seperti warna, rasa, tekstur dan aroma yang masih dapat diterima oleh panelis dengan skor 3,53. Berdasarkan gambar 5, urutan kesukaan panelis terhadap cookies almond crispy berturut-turut adalah perlakuan $\mathrm{B}, \mathrm{A}, \mathrm{D}$, C, E, dan F.

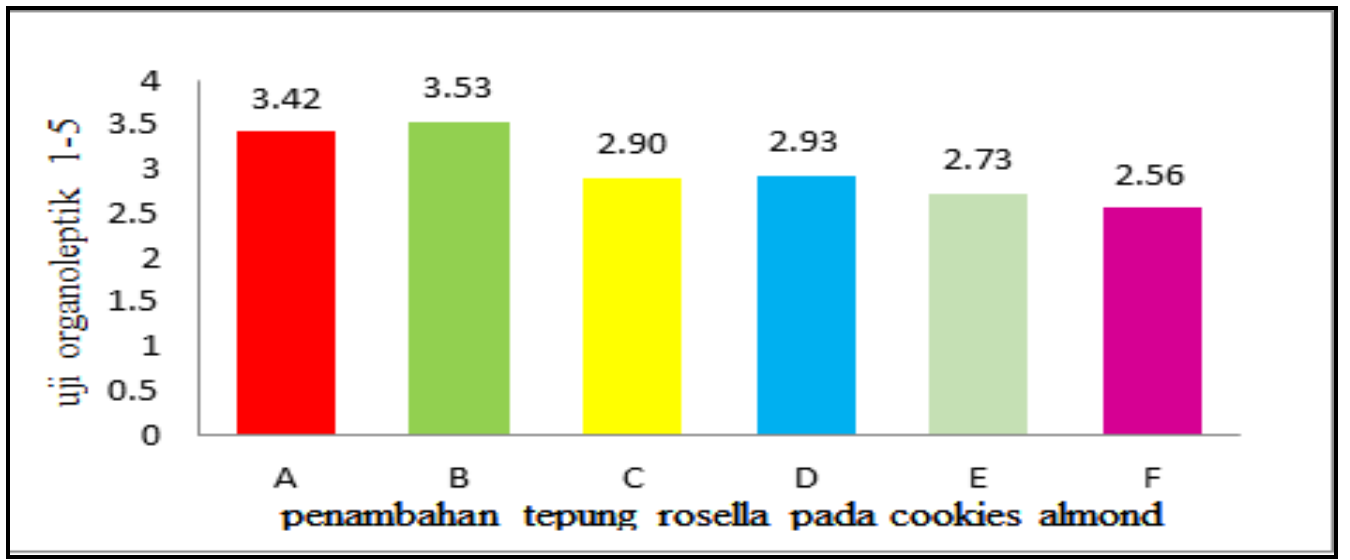

Gambar 5. Hasil Uji organoleptik Cookies almond Crispy dengan penambahan berbagai variasi konsentrasi tepung rosella.

Dari hasil uji Kruskal Wallis didapati Asymp.Sig. 0,000 yang lebih kecil dari tingkat signifikan 0,05 . Oleh karena itu, berdasarkan uji statistik maka disimpulkan bahwa semua perlakuan terbukti berbeda nyata terhadap kesukaan panelis terhadap semua parameter (warna, rasa, aroma, dan tekstur) cookies almond keju yang dihasilkan. Selanjutnya dilakukan uji Lanjut DMRT. Hasil dari uji lanjut DMRT pada perlakuan rasa dapat dilihat pada tabel 5 .

Tabel 5. Skor hedonik semua parameter cookies almond crispy dengan berbagai penambahan variasi konsentrasi tepung rosella

\begin{tabular}{cc}
\hline Perlakuan (\%) & Skor Warna \\
\hline A $(2,2 \%)$ & $3,42^{\mathrm{b}}$ \\
B $(3,3 \%)$ & $3,53^{\mathrm{b}}$ \\
C $(4,4 \%)$ & $2,90^{\mathrm{a}}$ \\
D $(5,5 \%)$ & $2,93^{\mathrm{a}}$ \\
E $(6,6 \%)$ & $2,73^{\mathrm{a}}$ \\
F $(0 \%)$ & $2,56^{\mathrm{a}}$ \\
\hline
\end{tabular}

Superskrip yang berbeda menunjukkan beda nyata $(\mathrm{P}=0,05)$.

\begin{tabular}{|c|c|c|}
\hline RUH & PENAMBAHAN & VARIASI \\
\hline ENTRASI & TEPUNG & ROSELLA \\
\hline darif & ffa Linn) TERHAI & OAP \\
\hline $\begin{array}{l}\text { ORGANOLEPTIK } \\
\text { CRISPY }\end{array}$ & COOKIES & ALMON \\
\hline
\end{tabular}


Berdasarkan uji DMRT menunjukkan semua parameter (warna, rasa, aroma, tekstur) cookies almond crispy dengan penambahan berbagai varian konsentrasi tepung rosella berbeda nyata. Konsentrasi tepung rosella memberikan pengaruh yang nyata terhadap semua parameter (warna, rasa, aroma, tekstur) cookies almond crispy. Dengan demikian, berdasarkan tabel 5 . perlakuan yang paling disukai berturutturut adalah perlakuan B, A, D, C, E, F.

\section{PENUTUP}

\section{Kesimpulan}

Kesimpulan dari penelitian ini adalah: Produk cookies almond crispy dengan penambahan varian konsentrasi tepung rosella yang paling baik dan diminati oleh panelis dari parameter warna adalah seluruh perlakuan penambahan konsentrasi tepung rosella, parameter rasa pada perlakuan penambahan konsentrasi tepung rosella 2,2\% dan 3,3\%, parameter aroma pada perlakuan penambahan konsentrasi tepung rosella 3,3 \% dan 4,4\%, dan parameter tekstur pada perlakuan penambahan konsentrasi tepung rosella 2,2 \% dan 3,3\%. Produk cookies almond crispy dengan penambahan varian konsentrasi tepung rosella yang paling baik dan diminati oleh panelis yaitu pada perlakuan penambahan konsentrasi tepung rosella sebanyak 3,3\%.

\section{DAFTAR PUSTAKA}

Agustini, S. 2006. Penelitian Pengaruh Metode Pengeringan dan Ukuran Partikel terhadap Mutu Teh Rosella. Dinamika Penelitian BIPA. 17 (29).

Nurfaridah, D. 2005. Bunga Rosella Penghias Taman Antihipertensi. http://.id.wikipedia.org/wiki/Bung a Rosella. Diakses pada tanggal 21 Oktober 2018

Olaleye, Mary Tolulope. Cytotoxicity and antibacterial activity of Methanolic extract of Hibiscus sabdariffa. Department of Biochemistry,
Federal University of Technology.

Diakses tanggal 10-8-2018.

Ojeda D, Jiménez-Ferrer E, Zamilpa A, Herrera-Arellano A, Tortoriello J, Alvarez L. Inhibition of angiotensin convertin enzyme (ACE) activity by the anthocyanins delphinidin- and cyanidin-3-Osambubiosides from Hibiscus sabdariffa. Centro de Investigaciones Químicas, Universidad Autónoma del Estado de Morelos;. Diakses tanggal 10-82018.

Oppel, M. 2007. Hibiscus Tea May Have Cholesterol-lowering Effects. Herbclip.http://www.herbalgram.o rg (12 September 2008)

Sartika, R.E.A 2018. Penemuan Yang Mengubah Dunia: Kue Kering Jamuan Untuk Perayaan. https:// sains.kompas.com. Diakses pada 7 Agustus 2018.

Puspita, S.S., Antasari, R. Tri, S. Wijaya, F. 2015. "Cornella" Cookies Bekatul Jagung dan Rosella Sebagai Snack Alternatif Pencegah Diabetes Mellitus. Skripsi. Jurusan Ilmu Kesehatan Masyarakat, Fakultas Kesehatan Masayarakat, Universitas Jember.

Rampengan, V.J dkk, 1985. Dasar-dasar Pengawasan Mutu Pangan. Badan Kerja sama Perguruan Tinggi Negeri Indonesia Bagian Timur, Ujung Pandang.

Riganakos, K.A., dan Kontominas, M. G. 1995. Effect of Heat Treatment on Moisture Sorption Behavior of Wheat Flours Using A Hygrometric Tehnique. G. Charalambous (Ed). Food Flavors : Generation Analysis and Process Influence. Hal 995.

Rostinawati, T. 2009. Aktivitas Antibakteri Ekstrak Etanol Bunga Rosella Terhadap (Hibiscus Sabdariffa L.) Escherichia coli, Salmonella typhi dan Staphylococcus aureus dengan 
metode difusi agar. Farmasi Unpad. Bandung.

Sri Boga Ratu Raya. 2005. Sekilas tentang tepung terigu dengan aplikasinya : Semarang

Suarni. 2009. Prospek pemanfaatan tepung jagung untuk kue kering (cookies). Balai Penelitian Tanaman Serealia. Maros. Jurnal Litbang Pertanian. 28 (2) : 63-68.

Sukotjo, Setiarti. 2003. Proses Pembuatan Keju Lunak. Serpong: CV. Chitra Delima

Soekarto. 1985. Penilaian Organoleptik untuk Industri Pangan dan Hasil Pertanian. Jakarta : Bharata Karya Aksara

Sutomo. 2009. Komposisi Kimiawi Kelopak Rosella. http://promdc.com/detailbungaro sella.php (17 Oktober 2018).

Tarwotjo, Soejuti. 2004. Dasar-Dasar Gizi Kuliner. Gramedia. Jakarta

Wikipedia, 2018. https://id.wikipedia.org/wiki/Rose la

Winarno, F.G. 1992. Kimia Pangan dan Gizi. PT. Gramedia Pustaka Utama. Jakarta.

Winarti, S, 2006. Minuman Kesehatan, Surabaya: Trubus Agri Sarana.

Widyanto, Poppy dan A. Nelistya. 2009. Rosella Aneka Olahan, Khasiat dan Ramuan. Depok : Penebar Swadaya.

Wulandari, N. 2003. Teknologi proses pengolahan susu kedelai sebagai minuman fungsional. Lokakarya Teknologi Proses Pengolahan dan Kualitas Minuman Fungsional Susu Kedelai. Bogor. 3-4 September 2003.
Wulandari, D. Ratna Puri, P. Kurnia W, R dan Nurkhasanah. 2014. Efek Imunostimulan Ekstrak Etanol Kelopak Bunga Rosella. Jurnal Farmasi Indonesia Vol. 7 No. 1 Januari.

Yuniastuti, A. 2003. Peran Pangan Fungsional Dalam Meningkatkan Derajat Kesehatan. Jurusan Biologi, FMIPA Universitas Negeri Semarang.



